\title{
AS MULHERES DO MST NA LUTA PELA TERRA E POR FAZER-SE EM SUJEITOS POLÍTICOS: RASTROS DA EXPERIÊNCIA ORGANIZATIVA NAS PÁGINAS DO JORNAL SEM TERRA
}

\author{
The women of the MST in the struggle for land and for making themselves into \\ political subjects: traces of organizational experience on the pages of Jornal \\ Sem Terra
}

lolanda Araujo Ferreira dos Santos'

Everton Lazzaretti Picolotto ${ }^{2}$

\begin{abstract}
Resumo
No surgimento do Movimento dos Trabalhadores Rurais Sem Terra o objetivo central era a luta pela terra, mas com foco na figura masculina como "trabalhador rural sem terra". A mulher era, nesse caso, apenas um membro da família sem terra, e o homem era o sujeito político, com poder e representatividade no movimento. Neste artigo buscamos elucidar qual o papel da mulher na luta pela terra e como o MST aborda e encara as questões de gênero. Para tanto, foram realizadas análises dos conteúdos das edições do Jornal Sem Terra, além da análise de cartilhas e cadernos de formação do MST que tratam da temática de gênero e feminismo, a fim de entender como a pauta das mulheres aparece nessas publicações. A luta das mulheres no MST é analisada nesse trabalho com base nas experiências organizativas vividas por estas no processo de fazer-se sujeito político. Assim, a partir das notícias do Jornal Sem Terra, foram delimitadas fases organizativas das mulheres no MST, que nos ajuda a compreender como se desenvolve a organização feminina no interior do Movimento, bem como suas principais pautas. Conclui-se que, desde o início do MST as mulheres iniciaram uma organização interna para reivindicar seus direitos enquanto sujeitos políticos e que o processo de incorporação das questões de gênero pelo MST é uma conquista da organização de mulheres, e não uma iniciativa espontânea do Movimento.
\end{abstract}

Palavras-chave: Mulheres Rurais, Gênero, Movimento dos Trabalhadores Rurais Sem Terra

\begin{abstract}
In the emergence of the Rural Landless Workers Movement (Movimento dos Trabalhadores Rurais Sem Terra - MST) the central objective was the struggle for land, but with a focus on the male figure as a "landless workers". The woman was, in this case, only a member of the landless family, and man was

\footnotetext{
1 Doutora em Extensão Rural pela Universidade Federal De Santa Maria (2019). Mestra em Extensão Rural pela Universidade Federal De Santa Maria (2015); Engenheira de Pesca pela Universidade Federal Rural de Pernambuco (2013). E-mail: iolanda_uast@yahoo.com.br. Cidade: Santa Maria - RS.

2 Professor Adjunto de Sociologia do Departamento de Ciências Sociais da Universidade Federal de Santa Maria. Professor dos Programas de Pós-Graduação em Ciências Sociais e Extensão Rural da UFSM. Coordenador do Programa de Pós-Graduação em Ciências Sociais da UFSM. Doutor em Ciências Sociais pelo CPDA/UFRRJ (2011). Pós-Doutorado em Sociologia pela UFPR (2012). Bacharel em Ciências Sociais (2003) e Mestre em Extensão Rural pela UFSM (2006). Email: everton.picolotto@ufsm.br. Cidade: Santa Maria - RS.
} 
As mulheres do MST na luta pela terra e por fazer-se em sujeitos políticos | lolanda Araujo F. dos Santos \& Everton L. Picolotto

the political subject with power and representativeness in the movement. In this article we seek to elucidate the role of women in the struggle for land and how the MST addresses the gender issues. Therefore, we analyzed the contents of the editions of Jornal Sem Terra, as well as the analysis of MST booklets and training books that deal with gender and feminism, in order to understand how the women's agenda appears in these publications. In this work, the struggle of women in the MST is analyzed based on the organizational experiences they lived in the process of becoming a political subject. Thus, with the news of the Jornal Sem Terra, were defined the organizational phases of women in the MST, which helps us understand how the women's organization within the Movement develops, as well as its main guidelines. It is concluded that since the beginning of the MST women have started an internal organization to claim their rights as political subjects and that the process of incorporating gender issues by the MST is an achievement of the women's organization, not a spontaneous initiative of the Movement.

Keywords: Rural Women, Gender, Movement of Landless Rural Workers

\section{Introdução}

A subordinação e consequente opressão às mulheres se constitui em todos os niveis da vida pública e privada e acabou por se tornar "regra" na sociedade em que vivemos. Para questionar e transformar essa "regra" emergem alguns movimentos sociais. Os movimentos sociais, de acordo com Melucci (2001), tem a capacidade de produzir novas formas de nomeação da realidade e desmascarar velhas maneiras de agir. Por essa perspectiva, teriam potencial de descortinar as diversas formas de desigualdade que geram a opressão de determinados grupos, como no caso escolhido, o das mulheres inseridas na luta pela terra.

O Movimento dos Trabalhadores Rurais Sem Terra (MST), enquanto movimento social que tem como foco central a luta por reforma agrária parte da problemática que envolve a luta de classes, reconhecendo a opressão entre classes. De acordo com Esmeraldo (2013), as ações politicas do MST (como as ocupações de terra) envolvem homens, mulheres, crianças e idosos e apresentam especificidades em relação a outros movimentos sociais com os quais mantém relação. O diferencial do MST com relação às demais organizações políticas (sindicato, partido político, por exemplo), é que o MST envolve toda a família nas suas lutas e manifestações politicas, sem separar a militância política da relação e condição conjugal. Isso, somado ao discurso de libertação econômica, social e política para a família trabalhadora rural faz com que o MST atraia e acolha mulheres fragilizadas pelo sistema econômico 
As mulheres do MST na luta pela terra e por fazer-se em sujeitos políticos | lolanda Araujo F. dos Santos \& Everton L. Picolotto

e político, submetidas a migrações com o marido e filhos em busca de terra e trabalho e dignidade para a familia (ESMERALDO, 2013).

Entretanto, mesmo seguindo essa perspectiva, as questões referentes à opressão de gênero tendem a ser reproduzidas dentro do Movimento dos Trabalhadores Rurais Sem Terra. Esmeraldo (2013) ressalta que a ação política das mulheres sem-terra é invisibilizada por sua condição conjugal, por conta da hegemonia de elementos discursivos e ideológicos estruturantes do movimento, fundamentados em uma visão produtiva e economicista da luta de classes, que por sua vez, se ancora centralmente na figura masculina como o provedor da família e como porta-voz do movimento.

É visivel a participação das mulheres na linha de frente dos confrontos políticos do MST, como nos atos públicos, nas marchas e acampamentos, onde, em geral, a presença de mulheres e crianças é destacada e valorizada. Entretanto, existem poucas mulheres em posições de liderança nos acampamentos, assentamentos e no próprio Movimento (DEERE, 2004). Assim, o engajamento político das mulheres do MST em diversas situações se deu sem um entendimento de que era uma luta específica ou diferenciada (BORDALO, 2011).

A década de 1980, época em que surge o MST, foi marcada pela expansão das lutas por direitos e pela participação das mulheres nos sindicatos, movimentos sociais, partidos políticos e demais espaços públicos, processo diretamente influenciado pelo movimento feminista da década de 1970, que ampliou as perspectivas e construiu novos percursos para as mulheres urbanas e rurais (BORDALO, 2011). Essa emergência dos movimentos populares trouxe um contorno politico para as questões de gênero, promovendo a conformação de espaços institucionais onde às mulheres questionavam as desigualdades de gênero e requeriam maior protagonismo político (BORDALO, 2011). O MST parece ter atentado para a necessidade de construir novas relações de gênero no interior do Movimento, após a organização das mulheres Sem Terra (Honório, 2005). De acordo com Gonçalves (2009), a própria dinâmica da luta pela terra levou as mulheres a organizar ações que provocaram questionamentos sobre a estrutura de poder expressa na organicidade do Movimento. 
As mulheres do MST na luta pela terra e por fazer-se em sujeitos políticos | lolanda Araujo F. dos Santos \& Everton L. Picolotto

A luta das mulheres no MST é analisada nesse trabalho com base nas experiências organizativas vividas por estas no processo de fazer-se sujeito político e identificadas a partir da análise das publicações do Jornal Sem Terra. A noção de experiência apresentada por Thompson (1981) se mostra útil para analisar a formação de consciências coletivas e de movimentos sociais, e também pode nos ajudar a entender a formação do sujeito político "mulher rural". Thompson (1981) destaca que a experiência surge a partir das vivências concretas dos indivíduos, categorias e classes sociais na história, pois homens e mulheres são seres racionais que refletem sobre o que acontecem a eles e ao mundo.

Neste artigo buscamos elucidar qual o papel da mulher na luta pela terra e como o MST aborda e encara as questões de gênero ${ }^{3}$. Para tanto, foram realizadas análises dos conteúdos das edições do Jornal Sem Terra, publicadas entre janeiro de 1985 e agosto de 2012, disponíveis no banco de dados digital "Hemeroteca Luta pela Terra" ${ }^{4}$ que totalizaram 278 edições. Analisamos também cartilhas e cadernos de formação do MST que tratam da temática de gênero e feminismo, a fim de entender como a pauta das mulheres aparece nessas publicações. Das 278 edições do Jornal Sem Terra que foram analisadas nessa pesquisa, buscou-se notícias com títulos que incluíam as palavras-chaves "mulheres", "camponesas", "agricultoras", "trabalhadoras rurais", "gênero" e "feminismo", dessa seleção chegou-se a um total de 107 edições $(38,5 \%$ das edições publicadas no período analisado) que apresentaram uma ou mais de uma notícia sobre as mulheres. Essas notícias foram lidas uma a uma e formam a principal base de informações que utilizamos para caracterizar as fases da experiência organizativa das mulheres no MST.

Com a análise das notícias do Jornal Sem Terra, complementada por Cadernos de Formação Cartilhas foi possivel realizar uma leitura geral sobre como a questão de gênero foi evoluindo para o conjunto do MST, bem como sobre as experiências organizativas empreendidas pelas mulheres que compõem esse Movimento, identificando as principais pautas levantadas por elas em determinados períodos. O percurso teórico-metodológico que nos

\footnotetext{
${ }^{3}$ Este artigo traz parte dos resultados da Tese de Doutorado da primeira autora.

4 Disponivel em: http://docvirt.no-ip.com/docreader.net/DocReader.aspx?bib=hemerolt\&pagfis=4937
} 
As mulheres do MST na luta pela terra e por fazer-se em sujeitos políticos | lolanda Araujo F. dos Santos \& Everton L. Picolotto

ajudará a entender como as experiências organizativas forjaram a mulher sem terra como sujeito político é baseado na noção de experiência indicada por Thompson.

$\mathrm{Na}$ tentativa de identificar as diferentes experiências organizativas empreendidas pelas mulheres no MST, além das notícias do Jornal Sem Terra (JST), recorremos, principalmente, aos trabalhos de Gonçalves (2009) e Deere (2004) que auxiliaram na periodização das experiências organizativas. Para facilitar o entendimento e a discussão, agrupamos as experiências, de acordo com o período em que aconteceram e as diferentes configurações organizativas, em "fases". O cotejamento das interpretações desses trabalhos sobre o tema com as notícias do JST nos levou à seguinte organização de três períodos históricos ou fases organizativas, que serão comentados nas sessões seguintes.

\section{Da conquista do direito à participação feminina ao "vazio organizativo" (1984 - 1995)}

A organização dos trabalhadores e trabalhadoras Sem Terra se inicia no Sul do Brasil ainda no final da década de 1970 com a deflagração dos primeiros acampamentos, mas é no ano de 1984 que é marcado, no MST, como sendo o ano de fundação oficial do Movimento e em 1985 se realizou o Primeiro Congresso Nacional do MST. No ano seguinte ao Primeiro Congresso Nacional, aconteceu o Primeiro Encontro Nacional de Mulheres do MST que originou a Comissão Nacional de Mulheres, primeira experiência de organização "oficial" das mulheres no MST. Essa comissão, criada em 1986, se desfaz em 1989.

O Primeiro Encontro Nacional da Mulher Trabalhadora Rural foi realizado no final de novembro de 1986, e a edição de novembro/dezembro de 1986 do JST traz uma matéria sobre esse evento. De acordo com a notícia, participaram desse encontro 35 lideranças femininas de 16 estados, para trocar experiências e se unir na luta por direitos. A principal discussão foi em torno da participação das mulheres nos sindicatos, movimentos populares e partidos políticos. As lideranças presentes no encontro discutiram que existem problemas específicos das mulheres que os movimentos e sindicatos não os assumem por não considerar prioritários, mas ponderaram que as próprias mulheres se acomodam esperando que alguém lute por seus direitos 
As mulheres do MST na luta pela terra e por fazer-se em sujeitos políticos | lolanda Araujo F. dos Santos \& Everton L. Picolotto

ou as convoque para participar. Diante dessa discussão foi encaminhada a realização de um trabalho de conscientização e organização das mulheres no Movimento e nos sindicatos, para que as mulheres lutem de igual para igual com os homens nas lutas gerais e também incidindo sobre seus problemas específicos. Sobre esse contexto, Furlin (2013) assinala que, ainda nos primórdios da trajetória do MST foram as mulheres que, mobilizadas, tomaram a iniciativa discutir os problemas relacionados à sua participação e aos seus direitos no interior do Movimento. Assim, além do Encontro Nacional da Mulher Trabalhadora Rural, do qual participaram mulheres rurais de sindicatos e movimentos sociais, as mulheres do MST organizaram em 1986 o I Encontro Nacional de Mulheres do MST, onde criou-se uma comissão de mulheres para discutir seus problemas e se articular internamente. Seria essa a primeira experiência organizativa formal das mulheres no interior do MST. De acordo com Deere (2004), a Comissão Nacional de Mulheres pressionou a criação de grupos de mulheres nos assentamentos e acampamentos, e também a criação de comissões estaduais de mulheres, que deveriam ser apoiadas pelas lideranças do Movimento.

A leitura das edições do Jornal Sem Terra publicadas nesse período nos permite uma análise preliminar sobre os temas que foram mais caros para as mulheres do MST nesta primeira fase De acordo com Esmeraldo (2013), após a importante participação das mulheres no $1^{\circ}$ Congresso do MST, em 1985, mulheres que já integravam assessorias da CPT, passam a fazer parte do MST e se responsabilizam pela veiculação da "Página da Mulher" no Jornal Sem Terra.

Em um primeiro momento, temos a reinvindicação nas páginas do JST pela participação feminina nas instâncias políticas do Movimento, que inicia com a mobilização das mulheres no $1^{\circ}$ Congresso e se mantém nas décadas seguintes. A luta das mulheres pela sindicalização é outra pauta importante, pois inclui o reconhecimento da mulher como trabalhadora rural e ainda a luta por direitos sociais e trabalhistas, como acesso à saúde, aposentadoria e licença maternidade. Após a formação da Comissão Nacional de Mulheres (1986), as notícias assumem um viés mais formativo com relação ao "papel da mulher". Iniciando com a publicação de um caderno de formação sobre a mulher nas diferentes sociedades, seguido por uma série de estudos sobre o 
As mulheres do MST na luta pela terra e por fazer-se em sujeitos políticos | lolanda Araujo F. dos Santos \& Everton L. Picolotto

papel da mulher. Algumas publicações reforçam a importância da participação da mulher na luta pela terra e também nos espaços políticos fora do Movimento, incentivando inclusive a participação das mulheres nas eleições municipais e estaduais.

Corroborando com o escrito por Esmeraldo (2013), entre as edições do Jornal Sem Terra analisadas nessa pesquisa, a primeira publicação diretamente relacionada às mulheres está na edição de fevereiro de 1985, e relata o empenho e a organização das mulheres no $1^{\circ}$ Congresso Nacional dos Sem Terra. De acordo com a notícia intitulada "Ao lado dos homens, sem medo da luta", as mulheres que estavam em número superior a 300, correspondendo a $20 \%$ do total de participantes, conseguiram participar dos grupos de trabalho do Congresso e ainda reuniram-se separadamente para discussão dos problemas específicos, assim garantiram lugar na Executiva Nacional do Movimento. O título da notícia chama a atenção pelo fato de destacar que as mulheres estão dispostas a encampar a luta do Movimento, da mesma forma que os homens. Nesta mesma edição do JST, sob o argumento de que "as mulheres foram um acontecimento à parte" no $1^{\circ}$ Congresso do MST, é apresentada uma entrevista com cinco lideranças femininas que estavam no congresso. Na entrevista, essas mulheres relatam a experiência na luta pela terra e reforçam a importância das mulheres se mobilizarem para conquistar espaços importantes no Movimento e na luta pela terra, como por exemplo, conseguir ocupar espaço na mesa do Congresso (que inicialmente era composta só por homens) e na Coordenação Nacional do Movimento, espaços estes que não seriam cedidos, mas que foram conquistados pelas mulheres presentes no Congresso. A entrevista também esclarece que muitas mulheres que estavam presentes nesse Congresso já tinham alguma apropriação do debate de gênero. Esmeraldo (2013) comenta que as mulheres participaram de forma ativa, afirmativa e organizada do $1^{\circ}$ Congresso do MST, reivindicando participação. Nesse congresso, a participação das mulheres se faz perceber de forma relevante pelo conjunto do movimento, especialmente pelo fato de que algumas dessas mulheres já tinham experiência de militância nas Comunidades Eclesiais de Base (CEBs), Comissão Pastoral da Terra (CPT), e oposições sindicais. Essa informação é importante para explicar a capacidade de articulação e mobilização das 
As mulheres do MST na luta pela terra e por fazer-se em sujeitos políticos | lolanda Araujo F. dos Santos \& Everton L. Picolotto

mulheres na luta por participação política no Congresso, pois, seguindo a noção de experiência explorada por Thompson (1981, p.16), de que "a experiência é o vivido, são os acontecimentos, e as ações e ao mesmo tempo o sentido a elas atribuído", as experiências políticas anteriores das mulheres que participaram desse I Congresso Nacional do MST contribuíram para que elas buscassem ocupar espaços e "fazer-se" enquanto sujeitos políticos dentro do Movimento.

Furlin (2013) também comenta sobre o I Congresso do MST, destacando que desde aí se percebia certa preocupação das lideranças em relação à participação feminina, e que mesmo sendo apenas $20 \%$ de participantes mulheres no I Congresso se estabeleceu que dali em diante pelo menos $30 \%$ dos participantes do congresso deveriam ser mulheres. Entretanto, em uma notícia do JST publicada na edição de fevereiro de 1988 revela-se que houve uma baixa participação das mulheres no IV Encontro Nacional dos Trabalhadores Rurais Sem Terra, onde a participação feminina não chegou a $20 \%$ do total de participantes. Nessa notícia, lideranças femininas falam ao Jornal Sem Terra que isso ocorre devido à falta de organização das mulheres e falta de preparação das mulheres para conquistar e se fazer presente nos espaços de decisão. No entanto, a literatura nos indica que a baixa participação das mulheres nesses espaços não é somente culpa da falta de organização - ou de vontade - delas. Paulilo (2004) chama atenção para o fato de que, nos movimentos que enfatizam as questões de classe, como é o caso do MST, o modelo de participação política privilegia a participação masculina:

\footnotetext{
O discurso da igualdade de gênero é consenso, mas não se discute quão desigual é essa igualdade, na medida em que se cobra das mulheres um comportamento masculino e elas acabam por incorporálo, sentindo-se culpadas quando não conseguem segui-lo à risca. Também esses movimentos tendem a criticar os movimentos autônomos de mulheres por considerá-los como radicais e separatistas (PAULILO, 2004, p. 239).
}

Demonstrando a influência da articulação das mulheres do MST com as mulheres sindicalistas, vimos que a importância da sindicalização das mulheres foi tratada em diversas edições de 1985 e 1986. De acordo com as notícias era comum que presidentes de sindicatos tentassem impedir ou dificultar a sindicalização das mulheres. Assim, para garantir e exercer esse 
As mulheres do MST na luta pela terra e por fazer-se em sujeitos políticos | lolanda Araujo F. dos Santos \& Everton L. Picolotto

direito as mulheres se mobilizavam em protestos, caminhadas e ocupações de sindicatos até que conseguissem o direito à sindicalização.

Apesar de não haver nenhum impedimento legal para a filiação das mulheres nos sindicatos rurais, era comum as diretorias se colocarem contra e tentar impedir que as mulheres se sindicalizassem (CARNEIRO, 1994). Para tentar sanar esse problema, após muita luta das mulheres, não só do MST, mas também das mulheres que atuavam na Contag, o IV Congresso da Confederação Nacional dos Trabalhadores Rurais (Contag), em dezembro de 1985, aprovou um documento qualificando a mulher como trabalhadora rural e estabelecendo formas de pagamento da mensalidade que não prejudicasse a renda familiar. Conforme apontado por Esmeraldo (2013), as regras instituídas nos documentos e nas práticas sociais são carregadas do senso comum, originados por tradições, valores e comportamentos que legitimam o homem na profissão de trabalhador rural e privam a mulher do acesso à terra, à capacitação e ao reconhecimento do seu trabalho. Infelizmente, segundo a autora, a prática e o discurso político no movimento sindical não contraria o que está posto. Os sindicatos continuaram a defender o gênero masculino como representação da categoria profissional de trabalhador rural, criando condições para que o homem acumule capital político e social para se manter como representante legitimo da classe trabalhadora rural (ESMERALDO, 2013).

Dado esse cenário, como assinalado pelos textos do JST, é importante que as mulheres não excluam a luta politica do espaço sindical, pois é no sindicato que devem buscar o reconhecimento formal de seu oficio, sendo essa a entidade capaz atribuir uma categorização profissional ao trabalho da mulher rural, possibilitando assim o acesso a direitos sociais, trabalhistas e previdenciários. Como assinala Esmeraldo (2013, p. 246):

\footnotetext{
Lutar para entrar no sindicato rompendo a unidade e as relações de forças historicamente constituídas para e com o masculino significa criar novas relações de forças não mais restritas às do gênero masculino, assim como de interesse do gênero feminino. Significa tencionar e inscrever reivindicações de interesse do outro, do novo gênero sindical, do gênero feminino.
}

Sobre a luta pela sindicalização é importante ressaltar que nos anos 1980 o MST, a o setor rural da Central Única dos Trabalhadores (CUT), a CPT e outras instituição sindicais eram muito próximas, dialogavam, cooperavam 
As mulheres do MST na luta pela terra e por fazer-se em sujeitos políticos | lolanda Araujo F. dos Santos \& Everton L. Picolotto

e trabalhavam juntos na conquista de terras e nas eleições sindicais de chapas progressistas contra outros setores sindicais considerados conservadores. A luta pela terra se unia à luta pelo fortalecimento dos sindicatos entre os setores populares (PICOLOTTO, 2011). O diálogo entre as mulheres dos sindicatos rurais e do MST foi o que originou a formação de movimentos autônomos, como o Movimento de Mulheres Trabalhadoras Rurais do RS e outros similares em outros estados. Bordalo (2011) ao estudar o Movimento de Mulheres Trabalhadoras Rurais do Nordeste, infere que a demanda das mulheres por maior participação política desmascara conflitos internos que estavam subordinados às orientações e estratégias relacionadas à "luta de classes". A questão de gênero dentro do MST, por exemplo, estaria subordinada às lutas gerais, e à superação da desigualdade de gênero seria consequência da superação da luta de classes. Segundo Bordalo (2011), foi essa hierarquização das lutas nos movimentos mistos que fez com que as demandas das mulheres fossem percebidas como questões específicas, fortalecendo assim a formação de redes e movimentos específicos de mulheres.

Nessa perspectiva, uma notícia na edição de junho de 1986 relata que as Trabalhadoras Sem Terra se reuniram para levar suas reinvindicações para o Congresso da CUT. Entre as pautas levadas pelas mulheres sem terra estão aposentadoria, reconhecimento da profissão, direito à assistência médica e também a discussão sobre a participação política das mulheres nos sindicatos. Sobre as reinvindicações femininas, Esmeraldo (2013) comenta que "elas, ao problematizarem o seu lugar nas relações de produção e o valor do trabalho feminino, produzem um sentido público para seu trabalho, politizam o mundo privado e levam a luta de gênero para a luta sindical" (ESMERALDO, 2013, p. 238). Ao questionar a hegemonia do homem no campo político, as mulheres buscam também se afirmar como sujeitos políticos e deixar de serem vistas como subordinadas na relação familiar, as mulheres reivindicam direitos de cidadania junto ao Estado, exigindo acesso a politicas previdenciárias como licença-maternidade e auxilio-doença (ESMERALDO, 2013). A mesma autora coloca ainda que as mulheres rurais constroem reivindicações específicas, como a luta por direito à sindicalização e por direitos previdenciários, para que possam se integrar e participar efetivamente do segmento de classe trabalhadora no MST. 
As mulheres do MST na luta pela terra e por fazer-se em sujeitos políticos | lolanda Araujo F. dos Santos \& Everton L. Picolotto

Como se pode perceber, a luta por sindicalização acontece de forma conjunta à luta por reconhecimento profissional e por direitos sociais. Uma importante vitória no contexto dessas lutas é trazida na edição de abril de 1986 do Jornal a notícia de que no dia 26 de março de 1986 o Ministério da Reforma e do Desenvolvimento Agrário publicou uma portaria que dá o direito à mulher trabalhadora rural de constar como titular de posse em projetos de assentamento. Assim, as mulheres solteiras e viúvas poderiam sair da condição de dependentes de irmãos ou pais. Apesar dessa ser uma vitória significante, as mulheres reivindicavam ainda o acesso ao Funrural ${ }^{5}$ de forma independente e os direitos previdenciários, além do reconhecimento como trabalhadoras rurais, e não "do lar". Até a Constituição de 1988, o homem rural tinha direito a apenas meio salário na aposentadoria, e as mulheres rurais não possuíam esse benefício. Essa situação era percebida como causadora de injustiças, uma vez que as famílias agricultoras eram contribuintes (pagavam uma taxa de $2 \%$ sobre os produtos comercializados para o Funrural), mas não estavam tendo acesso aos direitos que julgavam devidos. Para Coradini (1996, p.181) "apesar de haver um componente econômico evidente nas relações sociais estabelecidas (a 'contribuição' e o usufruo dos 'direitos'), há também um forte componente moral" como motivador dessas pautas políticas. Como se refere Thompson (1998, p.152), sobre os motins populares na Inglaterra: "é possivel detectar em quase toda ação popular do século XVIII uma noção legitimadora", a multidão estava imbuída da "crença de que estava defendendo direitos ou costumes tradicionais; e de que, em geral, tinha o apoio do consenso mais amplo da comunidade." Em sentido similar, os movimentos do campo (sindicatos, MST, etc.) lutavam pela aposentadoria integral para homens e pela inclusão das mulheres nos benefícios previdenciários. Essa luta por direitos sociais, de acordo com o retratado por Picolotto (2011), foi um dos grandes impulsionadores da organização das mulheres agricultoras no Sul do País.

A publicação "mulheres na luta" da edição de outubro/novembro de 1985 é uma divulgação do livro "Sangue na terra: a luta das mulheres", que

\footnotetext{
5 O fundo de Assistência e Previdência do Trabalhador Rural (Funrural) foi criado em 1963, a partir da aprovação do Estatuto do Trabalhador Rural, quando se deu a inclusão efetiva do trabalhador rural nos serviços de assistência e previdência. Os sindicatos teriam um papel fundamental na execução do Funrural (PICOLOTTO, 2011).
} 
As mulheres do MST na luta pela terra e por fazer-se em sujeitos políticos | lolanda Araujo F. dos Santos \& Everton L. Picolotto

fala sobre como as mulheres trabalhadoras rurais reagem à violência no campo, assumindo, por vezes, a liderança do Movimento após a morte de seus maridos. Mais que divulgar o livro, a notícia em questão divulga muitas mulheres que resistem na luta pela terra ${ }^{6}$, destacando sua posição de liderança e a lição de que a mulher não pode ficar "de braços cruzados". Carneiro (1994) aponta que foi a partir da década de 1980 as mulheres que participavam dos movimentos sociais no campo começaram a se reunir e promover encontros para discutir temas que lhes eram especificos. Antes dessa data as mulheres já participavam, mas sua participação se dava, geralmente, através de seus respectivos maridos, e nesses casos, o protagonismo da mulher só ocorreria com a morte de seu cônjuge, conforme coloca Carneiro (1994).

No Rio Grande do Sul, o Primeiro Encontro Regional de Mulheres da Roça ocorreu em agosto de 1987, cerca de 3.500 mulheres reuniram-se em Constantina conforme relatado na edição de setembro/1987 do JST. Trabalhadores e sindicalistas homens também participaram do encontro, todos enaltecendo a luta das mulheres. Ao final foi lido o documento com as reinvindicações das mulheres, que incluía a reforma agrária proposta pelo MST, organização das mulheres nos sindicatos, aposentadoria aos 50 anos com salário mínimo e assistência médica gratuita e de qualidade. No discurso final, a coordenadora nacional da organização das mulheres falou para suas companheiras que "para vencer as dificuldades devemos juntar nossas forças às dos homens, não criando movimentos paralelos, mas uma força única". Podemos notar com esse discurso que começa a ganhar força, mesmo entre as mulheres, o debate de que a organização de mulheres dentro do movimento poderia "dividir as forças" de forma a prejudicar o objetivo central do MST. Foi esse tipo de debate que começa a enfraquecer a Comissão Nacional de Mulheres até o ponto que essa organização se extingue no interior do MST e inicia o processo de emergência dos movimentos autônomos de mulheres, especialmente os Movimentos de Mulheres Trabalhadoras Rurais. As próximas notícias sobre as mulheres, até o fim desse período, são bem

\footnotetext{
6 Sobre a mulher como símbolo de resistência e luta, a edição de maio/1987 apresenta a história de Roseli Nunes, que foi assassinada enquanto participava de uma manifestação contra a polícia agrícola do Rio Grande do Sul, em março de 1987. Conforme a notícia, Roseli Nunes sempre esteve à frente das manifestações do Movimento dos Sem Terra e se tornou símbolo de luta e resistência pelo direito à terra.
} 
As mulheres do MST na luta pela terra e por fazer-se em sujeitos políticos | lolanda Araujo F. dos Santos \& Everton L. Picolotto

variadas e fragmentadas, o que reflete a falta de organização política das mulheres, ou pelo menos a falta de centralidade e organização das pautas de interesse específico das mulheres dentro do MST.

Inicialmente, a Comissão de Mulheres do MST ocupou um espaço no Jornal Sem Terra, onde divulgava os trabalhos realizados inserindo também temas para reflexão e formação sobre questões que envolvem a mulher rural, conforme apontado por Furlin (2013) esses temas foram posteriormente compilados no Caderno de Formação $\mathrm{n}^{\circ}$ 15, intitulado "A Mulher nas Diferentes Sociedades”. Esse Caderno, publicado em 1988 é uma publicação relevante no que tange à formação e reflexão sobre a condição da mulher na sociedade. O Caderno apresenta um caráter estritamente formativo, ao descrever a posição imposta às mulheres nas diferentes sociedades. O objetivo desse Caderno de Formação é "despertar sua atenção para questões que interessam à mulher e a toda classe trabalhadora" (MST, 1988, p.3). A orientação é que esse material servisse de discussão para o conjunto do Movimento.

O tema referente à participação da mulher na política se mostra relevante a partir de uma sequência de notícias, que inicia na edição de setembro de 1988, onde é publicada uma entrevista com as deputadas Luci Choinaski, de Santa Catarina, e Luiza Erundina, de São Paulo. As deputadas comentam sobre a necessidade que mulheres e homem lutem juntos contra o sistema opressor, sem dividir a luta. Elas falam ainda sobre as dificuldades que as mulheres enfrentam para conseguir conciliar uma vida politica com a vida em família.

É possível ler, na edição de agosto/1989 uma entrevista com quatro mulheres falando sobre a organização e luta das mulheres. Na entrevista, uma das coordenadoras do Movimento das Mulheres Trabalhadoras Rurais (MMTR) do RS, comenta que as reinvindicações da classe trabalhadora engloba as mulheres, mas a luta específica é pelo fim da discriminação e para que as mulheres cresçam junto com seus companheiros. Uma outra entrevistada, identificada como pequena agricultora de Santa Catarina, comenta que a luta das mulheres não é contra os homens, e sim contra o sistema que não possibilita a participação da mulher. O que observamos nessa notícia é a visibilidade dada às mulheres trabalhadoras rurais que não necessariamente 
As mulheres do MST na luta pela terra e por fazer-se em sujeitos políticos | lolanda Araujo F. dos Santos \& Everton L. Picolotto

são vinculadas ao MST e a tentativa de justificar a criação de movimentos autônomos de mulheres, no caso, o MMTR-RS.

De acordo com Deere (2004), a partir de 1989, a Comissão Nacional de Mulheres do MST parou de funcionar, principalmente pelo discurso de que a organização de mulheres no MST poderia "dividir a luta" e tirar o foco da prioridade do Movimento, que é a luta pela terra. Diante disso, as mulheres do Movimento foram orientadas a, caso se interessassem em discutir questões de gênero, buscar se organizar em movimentos autônomos de mulheres rurais, como o MMTR.

A extinção da Comissão Nacional de Mulheres não foi seguida de nenhuma outra forma de organização oficial em nível nacional no MST, assim a organização das mulheres ficou restrita aos movimentos autônomos. Por isso, o período de 1990 até 1995 é considerado por nós, nesse estudo como o período de "vazio organizativo" das mulheres no MST. Pois, ainda que, em alguns casos, as mulheres se mantivessem organizadas, em grupos e coletivos locais ou regionais, essas iniciativas não eram sustentadas nem apoiadas por uma organização nacional de mulheres no Movimento. O que observamos, nesse periodo, é, inicialmente, a continuidade de temas já tratados na fase anterior, como a importância da participação das mulheres nas eleições municipais e a luta das mulheres por direitos sociais. Além disso, temos um texto do MMTR que expressa a necessidade de as mulheres se organizarem em movimentos autônomos, afirmando, inclusive que os movimentos mistos não conseguem cumprir o papel de construção de uma nova sociedade com relação às questões de gênero. Esse discurso, de certa forma, justifica o fato de que o melhor seria as mulheres se organizarem fora do MST.

As notícias finais desse período de "vazio organizativo" chamam atenção pelo fato de se voltarem para discutir sobre a baixa participação das mulheres nos processos de decisão do MST, e as dificuldades que as mulheres enfrentam para conseguir participar. Uma característica importante desse período é a fragmentação e dispersão de temas, além de uma diminuição nas publicações referentes às mulheres, o que demonstra que a falta de uma organização formal de mulheres no MST reflete nas edições do Jornal Sem Terra que passa a publicar menos sobre temas referentes às mulheres. Contudo, as notícias ainda que fragmentadas, revelam que algumas 
As mulheres do MST na luta pela terra e por fazer-se em sujeitos políticos | lolanda Araujo F. dos Santos \& Everton L. Picolotto

experiências organizativas no nível local e regional continuam sendo alimentadas, contribuindo para a formação de lideranças políticas femininas. Por fim, uma notícia sobre o Congresso do Movimento de Mulheres Agricultoras de Santa Catarina em 1994, sinaliza que o MST estava atentando para a organização de mulheres, e considerando a importância de alianças com os movimentos autônomos.

Sobre a importância da participação das mulheres na política, com o título "a coragem das trabalhadoras rurais", a edição de julho/agosto de 1990 do Jornal Sem Terra traz uma entrevista com a deputada Luci Choinaski, onde a deputada reforça que a mulher precisa estar em cargos de direção política, entretanto ressalta as dificuldades em enfrentar a discriminação, pois a mulher precisa provar que é capaz de assumir esses cargos. A importância de ter uma mulher em cargos políticos decisivos no cenário nacional é bem exemplificada na notícia de abril de 1994, referente ao Projeto de Lei de autoria da Deputada Luci Choinaski que concede às trabalhadoras rurais o direito ao salário maternidade.

Na edição de janeiro/fevereiro de 1994 encontra-se uma entrevista com a segunda mulher a fazer parte da direção nacional do MST onde a entrevistada fala sobre as dificuldades colocadas para a participação da mulher, mas afirma que as mulheres estão mais conscientes do valor de sua contribuição e por isso tem participado mais ativamente. Chama atenção nessa notícia o fato de que, de acordo com o publicado no JST, em 1994 é a segunda vez que uma mulher assume cargo na direção nacional, ou seja, quase 10 anos após a formação oficial do Movimento apenas duas mulheres participaram da direção nacional. A primeira mulher teria ocupado a direção nacional na ocasião do Primeiro Congresso do MST. Entretanto, em cartilha mais recente publicada pelo Setor de Gênero do MST, se afirma que no Primeiro Congresso Nacional do Movimento duas mulheres faziam parte da direção nacional, então a partir do cruzamento desses dados, podemos inferir que até 1994 se contabiliza três mulheres na direção nacional do MST.

O Jornal Sem Terra apresenta na edição de setembro/1994 uma entrevista a uma das coordenadoras do Movimento de Mulheres Agricultoras de Santa Catarina sobre o I Congresso de Mulheres Agricultoras e sobre a comemoração de 10 anos do Movimento. Entre os temas tratados no congresso 
As mulheres do MST na luta pela terra e por fazer-se em sujeitos políticos | lolanda Araujo F. dos Santos \& Everton L. Picolotto

estão a participação política da mulher na sociedade e a luta de gênero e classe. No congresso foi reafirmado a importância do trabalho de base com as mulheres e foi tirado como meta uma aliança mais próxima com o MST para concretização da luta pela reforma agrária. Nota-se aí que, apesar de ter se aberto mais espaço para os movimentos autônomos de mulheres, inicia-se um processo de articulação entre os movimentos autônomos e o MST, o que contribui para que o MST volte a se preocupar com as questões de gênero.

Demonstrando que as mulheres do MST persistem na pauta de luta por direitos sociais, a edição de março de 1992 do Jornal Sem Terra publica uma notícia intitulada "Mulheres na luta", que relata como mulheres rurais se mobilizaram em Brasília para derrubar o veto de Collor às questões fundamentais de direitos da mulher. Ainda sobre o tema da luta por direitos sociais, a edição de dezembro de $1993^{7}$ traz uma notícia intitulada "mulheres agricultoras unidas pelos seus direitos", que relata que em Santa Catarina cerca de 150 mulheres agricultoras de dois assentamentos de Calmon-SC se reuniram no "Encontro de Mulheres".

O tema do salário maternidade aparece novamente na edição de abril de 1994, que noticia essa importante conquista das mulheres trabalhadoras rurais. De acordo com o publicado, em 25 de março de 1994 o Presidente Itamar Franco sancionou o projeto de Lei de autoria da deputada Luci Choinaski, que concede às trabalhadoras rurais o direito ao salário maternidade, após quase cinco anos de luta.

Para acessar aos direitos sociais, era necessário primordialmente que as mulheres trabalhadoras rurais possuíssem documentação pessoal, assim a edição de novembro de 1994 traz um box intitulado "Nenhuma trabalhadora rural sem documentos" com a divulgação de uma cartilha organizada pelo Movimento de Mulheres do Paraná, que orienta as agricultoras a tirar seus documentos para poder acessar seus direitos. A pauta de documentação da mulher trabalhadora rural foi alvo de uma campanha do MST, visto a necessidade de que todas as trabalhadoras estivessem aptas à acessar os direitos sociais que iam sendo conquistados, entretanto essa não é uma

\footnotetext{
7 No decorrer do ano de 1993 não se verificou nenhuma postagem, além desta, sobre as mulheres, nem mesmo sobre o "8 de março". A edição de Abril - 1993 fala sobre as jornadas de lutas de março e não cita nenhuma mobilização de mulheres.
} 
As mulheres do MST na luta pela terra e por fazer-se em sujeitos políticos | lolanda Araujo F. dos Santos \& Everton L. Picolotto

iniciativa só do MST, mas sim um movimento nacional articulando com movimentos sociais e sindicatos.

"Mulher que luta organizada gera nova sociedade" é o titulo do texto do Movimento de Mulheres Trabalhadoras Rurais do RS, sobre a existência de um movimento autônomo de mulheres. Esse texto consta na edição de maio/junho de 1992 do Jornal Sem Terra. De acordo com o texto o que o movimento de mulheres objetiva é rediscutir os papéis sociais e as relações de exploração e dominação, e como essas relações se articulam com a organização política, econômica, social e cultura da sociedade.

A prática politica das mulheres nos movimentos autônomos demonstra uma participação ativa e protagonista das mulheres nas lutas pelos seus direitos. Essa postura afirmativa e propositiva das mulheres rurais não é devidamente reconhecida no interior do MST nas décadas de 1980 e 1990, onde, embora esse movimento se constitua como movimento de homens e mulheres, apresenta na prática uma representação política hegemonicamente masculina, sendo a presença da mulher marcada por uma participação invisível e omitida (ESMERALDO, 2013). Nesse sentido, é importante observar que a conquista de representação e reconhecimento só é materializada a partir das lutas empreendidas pela auto-organização das mulheres.

\section{A retomada de responsabilidade com as questões de gênero no MST e a expansão do debate para os homens (1995 - 2002)}

No final de 1995, foi realizado um Encontro Nacional de Mulheres, em São Paulo, do qual participaram diversas organizações de mulheres rurais com o objetivo de criar a Articulação Nacional de Mulheres Trabalhadoras Rurais, a ANMTR ${ }^{8}$. Participaram desse encontro várias mulheres líderes Sem Terra, que conseguiram, a partir das discussões de gênero ocorridas nesse evento levar esse debate para dentro do MST novamente, e organizar em 1996 o $1^{\circ}$ Encontro Nacional de Mulheres Militantes do MST, que originou o Coletivo Nacional de Mulheres (DEERE, 2004). Com esse coletivo, o Movimento passa a ter uma organização oficial de mulheres, em nivel nacional, o que, de acordo com Derre (2004), significa que o Movimento passa a também assumir

\footnotetext{
8Articulação Nacional de Mulheres Trabalhadoras Rurais reuniu mulheres dos seguintes movimentos: Movimentos Autônomos, Comissão Pastoral da Terra - CPT, Movimento dos Trabalhadores Rurais Sem Terra - MST, Pastoral da Juventude Rural - PJR, Movimento dos Atingidos pelas Barragens - MAB, Sindicatos de Trabalhadores Rurais e Movimento dos Pequenos Agricultores - MPA.
} 
As mulheres do MST na luta pela terra e por fazer-se em sujeitos políticos | lolanda Araujo F. dos Santos \& Everton L. Picolotto

responsabilidade com as questões de gênero, não mais deixando essa pauta apenas para os movimentos autônomos de mulheres.

Essa fase de retomada do debate de gênero no interior do MST é intensa, marcada principalmente pela discussão sobre o papel da mulher na luta pela reforma agrária e sobre a importância de combinar questões de classe e gênero para que o MST assuma de fato uma responsabilidade na construção de novas relações de gênero.

A experiência histórica do Movimento mostrava que assim como as mulheres eram fundamentais na luta pela terra, as suas pautas também deveria ser no interior do MST na construção de novas relações de gênero. Pois, como reforça Thompson (1981), "a experiência é um termo médio necessário entre o ser social e a consciência social”:

\begin{abstract}
Os homens e mulheres também experimentam suas situações e relações produtivas determinadas como necessidades e interesses e como antagonismos, e em seguida "tratam" essa experiência em sua consciência e sua cultura das mais complexas maneiras e em seguida agem, por sua vez, sobre sua situação determinada." (THOMPSON, 1981, p. 182)
\end{abstract}

Assim podemos inferir que é a experiência, ou a experimentação de situações e relações que produzem a consciência de classe, ou no caso das mulheres rurais, que produzem a consciência de classe e gênero e a reivindicação de espaços próprios para a sua organização interna.

Nessa perspectiva, após a criação do Coletivo Nacional de Mulheres, as notícias do JST são sobre a intensificação o debate de gênero nos movimentos camponeses, intensificação demonstrada nas diversas notícias com chamadas para encontros de mulheres rurais (nacionais e internacionais ${ }^{9}$ ) e notícias sobre a criação de organizações regionais de mulheres. Entre as notícias de eventos, encontramos a publicação sobre o II Encontro Nacional de Mulheres, realizado em 1998, que dá mais força para a discussão sobre a importância da organização e pressão interna das mulheres no MST. Os diversos encontros de mulheres realizados nessa fase são exemplo da experiência de estruturação das mulheres no interior do MST, e de como tem crescido no Movimento o debate sobre gênero.

\footnotetext{
9 A edição de fevereiro de 1998 traz uma nota do Coletivo de Mulheres desafiando as companheiras a organizar uma brigada para participar do Encontro de Solidariedade entre Mulheres em Cuba, que seria realizado em abril de 1998.
} 
As mulheres do MST na luta pela terra e por fazer-se em sujeitos políticos | lolanda Araujo F. dos Santos \& Everton L. Picolotto

"Sem a luta das mulheres as conquistas ficam pela metade" é esse o título de uma notícia publicada na edição de novembro de 1995 do Jornal Sem Terra. A notícia relata o I Encontro Nacional de Mulheres Trabalhadoras Rurais que aconteceu no Instituto Cajamar-SP, em outubro de 1995. Nesse encontro, trabalhadoras de diversas organizações do campo discutiram uma proposta de articulação nacional para enfrentar o projeto neoliberal do governo do então presidente Fernando Henrique Cardoso e seus ataques aos direitos das trabalhadoras rurais, conquistados com muita luta. Durante os debates desse Encontro foi consenso que gênero e classe se entrelaçam e que a combinação dessas lutas é necessária para a construção de um projeto de sociedade democrático e popular. Essa conclusão contrapõe as práticas de opressão às mulheres que muitas organizações da classe trabalhadora reproduzem, especialmente em deixar as reinvindicações das mulheres em segundo plano.

Seguindo a mesma linha da necessidade de articular as lutas de classe e gênero, na edição de março de 1996 encontramos uma entrevista com uma mulher da direção estadual do MST-RS. Na entrevista intitulada "o MST deve lutar também contra o machismo", a dirigente fala sobre a questão da mulher na luta pela reforma agrária. Para ela a mulher trabalhadora rural é duplamente explorada, porque sofre enquanto classe e sofre pelo fato de ser mulher. Essa dirigente afirma que o desafio do MST é aceitar que as mulheres têm muito a contribuir para a luta, do ponto de vista político, é preciso que o movimento coloque em prática mecanismos que garantam participação efetiva das mulheres em todos os processos, pois sem a participação da mulher o MST perde.

"Mulheres do MST discutem seus problemas na luta pela reforma agrária" é o título de uma publicação da edição junho/1996. A publicação relata que 43 mulheres militantes do MST se reuniram entre os dias 25 e 28 maio de 1996 para discutir a questão da mulher na luta pela Reforma agrária. No encontro as mulheres tiveram espaço de estudo e formação sobre as questões de gênero na sociedade e a partir daí foram levantados problemas que as mulheres enfrentam na luta pela terra e dentro do próprio Movimento. $\mathrm{Na}$ discussão as mulheres pontuaram que nos assentamentos e 
As mulheres do MST na luta pela terra e por fazer-se em sujeitos políticos | lolanda Araujo F. dos Santos \& Everton L. Picolotto

acampamentos se reproduz a opressão às mulheres e que isso se reflete na pouca representação feminina nas instâncias do MST.

A edição de julho de 1996 traz uma publicação sobre a ANMTR. De acordo com a publicação, a Articulação Nacional de Mulheres convocava todas as trabalhadoras rurais para mobilização nacional no dia 12 de agosto de 1996, data que marca treze anos do assassinato de Margarida Alves ${ }^{10}$. Essa articulação surgiu a partir da importância da luta conjunta e não isolada, e também da necessidade de trabalhar de uma forma diferente com as mulheres dos movimentos sociais do campo, que participavam da luta de forma silenciosa e com pouca participação nas instâncias de decisão dos movimentos. Outra notícia da edição de outubro/novembro de 1996 ("Mulheres latino-americanas se organizam no campo") trata da intensificação do debate em torno da questão de gênero nos movimentos camponeses, inclusive ressaltando a intensa participação das mulheres na construção da Via Campesina. A Via Campesina é uma articulação internacional popular de organizações camponesas que surge em 1993 e se dispõe a enfrentar o capitalismo e defendem um projeto alternativo de desenvolvimento, baseado sobretudo na soberania alimentar. É interessante observar que nesse período em que se inicia a articulação do MST com a Via Campesina, se assume também o compromisso com a agroecologia que é uma das principais bandeiras da Via Campesina.

Além das notícias, cabe nessa fase citar a cartilha "A questão da Mulher", que traz o plano de trabalho e encaminhamentos do I Encontro Nacional das Mulheres Militantes do MST que aconteceu entre 25 e 28 de maio de 1996. De acordo com a cartilha, nesse Encontro foi discutido sobre a histórica construção da dominação de gênero, e como essa dominação se manifesta internamente no MST. Furlin (2013) destaca que, na realização desse Encontro as mulheres estavam mais articuladas e contavam com o apoio do Movimento para sua auto-organização e foi a partir daí que surgiu a ideia da cartilha (FURLIN, 2013). Esse material de formação foi destinado a

\footnotetext{
10 Margarida Maria Alves foi assassinada em 12 de agosto de 1983. Ela foi presidenta do Sindicato dos Trabalhadores Rurais de Alagoa Grande, na Paraíba. Três meses antes de morrer, em um discurso de comemoração pelo $1^{\circ}$ de maio (Dia do Trabalhador), ela disse que "é melhor morrer na luta do que morrer de fome". Seu legado inspira a luta das mulheres trabalhadoras rurais e dá nome a "Marcha das Margaridas", evento promovido em nível nacional a cada quatro anos pela Contag, MST e outros movimentos.
} 
As mulheres do MST na luta pela terra e por fazer-se em sujeitos políticos | lolanda Araujo F. dos Santos \& Everton L. Picolotto

todos os membros do MST para servir como roteiro de estudo e reflexão nas bases.

O principal desafio colocado pelas mulheres na cartilha é "como construir novos valores e novas relações no cotidiano, vinculando a participação das mulheres". Como meios para avançar nesse sentido, foram destacados a importância do trabalho de base e da formação politica e a necessidade de criar condições objetivas para a participação das mulheres nas instâncias do Movimento. Entretanto, as cotas que estabelecem número mínimo de mulheres nos espaços é colocada como uma "ilusão" que sozinhas não resolveriam o problema (MST, 1996).

Na segunda parte da cartilha tem-se a exposição de documentos do MST que abordam a questão da mulher, o que mostra a evolução de como essa questão está sendo pensada e orientada na sua linha política. Entre esses documentos está as Normas Gerais do MST, de 1989, que explicita que se deve "estimular a participação das mulheres em todos os níveis" e lutar contra o machismo que impede a igualdade de condições e direitos. As normas gerais do MST também recomendam a criação e comissões e grupos de mulheres nos acampamentos e assentamentos, bem como uma equipe nacional de mulheres para pensar e propor políticas específicas e orientar o trabalho específico com mulheres, assim como elaborar materiais sobre o tema (MST, 1996).

O Documento Básico, de 1993, também é citado por apresentar em seu artigo 45 que a organização do MST deve considerar as questões específicas das mulheres e sua participação, tratando como classe e não enquanto gênero. Percebe-se então o esforço do Movimento em vincular as pautas das mulheres às questões de classe, como tentativa de evitar a "divisão da luta" entre homens e mulheres. Nesse mesmo documento, no artigo 152 sobre a produção, tem-se que é preciso garantir a participação das mulheres na cooperação agrícola e no trabalho produtivo, de forma a combater o tradicionalismo do meio camponês (MST, 1996, grifo nosso).

Outro documento citado na cartilha é o Programa Agrário, de 1995, que tem um tópico sobre "a situação da mulher no campo". Neste documento é ressaltado que as mulheres do campo realizam dupla jornada de trabalho (lavoura e casa) sem, muitas vezes, receber nada pelo trabalho realizado, além de serem impossibilitadas de participar das decisões da economia familiar. 
As mulheres do MST na luta pela terra e por fazer-se em sujeitos políticos | lolanda Araujo F. dos Santos \& Everton L. Picolotto

Destaca-se ainda que a prática do machismo no meio rural submete a mulher a uma condição inferior. Neste mesmo documento, consta entre os objetivos gerais do MST: "combater todas as formas de opressão e buscar a participação igualitária da mulher" (MST, 1996).

A terceira parte da cartilha é onde se explicita o plano de trabalho construído no Encontro Nacional de Mulheres do MST. Em geral os objetivos do plano de trabalho são construir novos valores, ter as questões de classe e gênero como princípio, e criar mecanismos que possibilite, massifique e qualifique a participação das mulheres em todos os niveis. Para tanto, foram pensadas algumas ações específicas a serem colocadas em prática nos acampamentos e assentamentos, nas instâncias do MST, e entre as mulheres militantes (MST, 1996).

Levando em conta a baixa presença das mulheres nos postos de direção da organização, as ações pensadas para os acampamentos e assentamentos com vistas a tornar mais efetiva a participação feminina envolvem desde o processo de conscientização sobre a necessidade da participação das mulheres na luta pela terra, até a projeção de lideranças para as instâncias. Também é previsto no plano de ação a realização de encontros municipais e reuniões entre mulheres e ainda a garantia de participação das mulheres nas associações e cooperativas e a titularidade do lote. Para que a participação das mulheres seja possibilitada é necessário adequar o horário de reuniões de acordo com a disponibilidade delas (MST, 1996).

As ações previstas para as instâncias do MST são, em geral, no sentido que todos os setores discutam e estudem sobre a questão de gênero e a criação de mecanismos de participação. É necessário ainda que as instâncias assumam que existem problemas para a participação das mulheres e que se projete quadros femininos. Entre as mulheres militantes o previsto é o trabalho com a autoestima e identidade, para que essas mulheres se fortaleçam e assumam uma postura a partir dos "novos valores" e assim possam reproduzi-los. Também seria tarefa das mulheres militantes criar fóruns de discussão e capacitação (MST, 1996).

O II Encontro Nacional de Mulheres do MST aconteceu em outubro de 1997 e foi retratado em uma notícia da edição de janeiro de 1998 do JST. De acordo com a notícia o encontro animou as companheiras e serviu para 
As mulheres do MST na luta pela terra e por fazer-se em sujeitos políticos | lolanda Araujo F. dos Santos \& Everton L. Picolotto

consolidar a articulação das mulheres. Os debates realizados no Encontro também ajudaram a aprofundar a discussão sobre gênero e poder. Conforme assinalado na notícia:

Para as companheiras do MST, o poder não deve ser concedido às mulheres como um favor. Deve ser uma conquista. É preciso, então, criar condições e intensificar a formação, articulação e organização das mulheres, para que elas participem das instâncias, busquem se qualificar e passem a fazer parte dos processos de decisão da nossa organização.

A organização e realização de encontros locais e regionais de mulheres são expressões da mobilização das mulheres por um maior protagonismo.

Com a intensificação do debate de gênero, o então Coletivo Nacional de Mulheres, se transforma em Coletivo Nacional de Gênero, no ano de 1999, composto agora por homens e mulheres, a partir de um debate de que as questões de gênero precisam ser discutidas não só entre as mulheres, mas também com os homens que compõem o MST (DEERE, 2004). Esse é outro momento organizativo das mulheres, em que a própria mudança de nome do coletivo, que deixou de ser "de mulheres" para ser "de gênero", já indica que se almejava ampliar o debate de gênero não o restringindo às mulheres.

Nesse contexto de formação do Coletivo Nacional de Gênero, percebese nas notícias uma ênfase, na luta das mulheres, para que o Movimento entendesse a importância da participação politica das mulheres e sobre a necessidade de que o MST aprofunde o debate de gênero no seu conjunto. Outras notícias desse período são relacionadas à importância da mulher trabalhadora rural nas lutas sociais, mostrando a mobilização não só de mulheres do MST, mas dessas em conjunto com demais mulheres rurais organizadas na Articulação Nacional de Mulheres Trabalhadoras Rurais para garantir direitos sociais e lutar contra transgênicos e agronegócio.

A aproximação do MST com a Via Campesina no final dos anos 1990, ao mesmo tempo em que o Movimento se afasta da CUT são fatores que influenciam no debate interno, inclusive com relação às questões de gênero. Também nesse período as mulheres do MST passam a se mobilizar mais em torno da identidade de "Mulher Camponesa" e, assumindo o tema da Agroecologia, as mulheres também passam assumir o projeto de desenvolvimento agroecológico, intensificando esse debate no próximo período 
As mulheres do MST na luta pela terra e por fazer-se em sujeitos políticos | lolanda Araujo F. dos Santos \& Everton L. Picolotto

organizativo. Nos anos seguintes, esses temas vão aparecendo com maior frequência e importância nas páginas do JST.

A primeira notícia do Coletivo Nacional de Gênero é intitulada "Mulheres na luta por uma nova sociedade", em comemoração ao 8 de março, publicada na edição de março de 1999 do JST. A notícia destaca a luta das mulheres, colocando que depois de 15 anos de muita luta e discussão se avançou no entendimento da importância da participação da mulher no Movimento:

"Hoje, na base, estamos estimulando e organizando os coletivos e
grupos de mulheres nos acampamentos, assentamentos. Em nivel
regional, estadual e nacional, estamos criando os coletivos de gênero
que tem, entre outras, as tarefas de: aprofundar a questão de gênero
no conjunto da organização, elaborar a parte teórica sobre a questão,
propor atividades para o conjunto do MST e animar o debate interno."

A edição de abril/2000 traz um relato do I Acampamento Nacional de Mulheres Trabalhadoras Rurais, organizado pela ANMTR que aconteceu entre os dias 13 e 17 de março, em Brasília. Esse acampamento reuniu cerca de 3000 mulheres de todo país. As discussões realizadas no acampamento e a mobilização das trabalhadoras as fortaleceu e trouxe mais reconhecimento para a importância da mulher trabalhadora rural nas lutas sociais.

As edições de maio de 2000 e janeiro de 2001 destacam a força da mobilização das mulheres, falando respectivamente sobre uma ocupação de terras realizada exclusivamente por mulheres e sobre a ocupação da sede do Instituto Nacional de Colonização e Reforma Agrária (Incra) em São Paulo por mulheres e crianças. As notícias destacam que as mulheres enfrentam a repressão e lutaram contra a concentração de terras e contra as injustiças cometidas frente aos militantes do Movimento.

Essa mesma edição (janeiro/2001) noticia ainda que foi reconhecido que a mulher tem o direito de ter o título da terra em seu nome, se vive junto com um companheiro o título pode sair no nome de ambos, mesmo que não exista documentos que comprovem casamento. E no caso de mulheres maiores de idade, solteiras, viúvas ou divorciadas podem ter o título da terra apenas em seu nome. Esses direitos se estendem aos financiamentos do Programa Nacional de Apoio para a Agricultura Familiar (Pronaf) e todos os créditos oferecidos pelo Incra nos assentamentos. Esses direitos já estavam reconhecidos na constituição de 1988, mas não se aplicava na prática, ficando 
As mulheres do MST na luta pela terra e por fazer-se em sujeitos políticos | lolanda Araujo F. dos Santos \& Everton L. Picolotto

a mulher numa posição de submissão à figura masculina. Assim, a conquista do direito a titularidade do lote é uma vitória significativa para a luta das mulheres.

Em março de 2001 o JST publica uma notícia intitulada "Mulheres trabalhadoras rurais na luta por um novo Brasil". Segundo essa notícia, entre os dias 5 e 9 de março de 2001, um número aproximado de 24 mil mulheres participaram da Mobilização Nacional de Mulheres Trabalhadoras que promoveu ações em todos os estados do país. As mulheres protestaram contra o modelo agrícola e agrário e fizeram reivindicações específicas, especialmente sobre saúde e previdência para as trabalhadoras rurais. Essa mobilização foi organizada pela ANMTR. Entre as pautas de reivindicação estão: o assentamento imediato de todas as famílias acampadas no país, a aprovação da lei que estabelece limite máximo de propriedade rural, revogação da Medida provisória que proíbe a ocupação de terras, extinção do Banco da Terra e do crédito fundiário, exigência da inclusão da mulher como titular do lote, veto aos transgênicos, fim das importações agrícolas, direitos humanos no campo, moradia, educação e saúde.

O Caderno de Formação n 02, intitulado "Mulher Sem Terra" é uma publicação de responsabilidade do Coletivo Nacional de Gênero do MST e representa a construção coletiva de um processo de 15 anos de luta pelo fortalecimento da participação das mulheres (MST, 19-) ${ }^{11}$. Ao contrário da Cartilha "A questão da mulher" de 1996, anteriormente comentada, que serviria para todos os membros do movimento, o Caderno de Formação $n^{\circ} 02$ é especificamente direcionado para as mulheres, nele consta a orientação para realização de encontros que serviriam para reflexão da condição da mulher na sociedade e no MST e também como aporte para fortalecimento da organização e mobilização das mesmas.

No final dos anos de 1990 e início dos anos 2000, o espaço organizativo das mulheres ganha um pouco mais de visibilidade com a sua consolidação no debate sobre gênero no Movimento e pela entrada de novos temas, motivados pela filiação à Via Campesina. Essas marcas serão melhor notadas no período seguinte.

11 Não encontramos o ano exato de publicação desse Caderno de Formação. 
As mulheres do MST na luta pela terra e por fazer-se em sujeitos políticos | lolanda Araujo F. dos Santos \& Everton L. Picolotto

\section{Um salto de importância para o debate: a implementação do Setor Nacional de Gênero (2003 - 2012)}

No IV Congresso Nacional do MST, no ano de 2000, foi aprovada a criação do Setor Nacional de Gênero, entretanto, essa estrutura organizativa só passou a operar efetivamente a partir de 2003, com a dissolução do Coletivo Nacional de Gênero (GONÇALVES, 2009). Com a instituição do Setor Nacional de Gênero, o debate e a organização das mulheres ganharam mais importância e visibilidade para o Movimento como um todo. Essa seria uma nova fase organizativa das mulheres no MST, onde estas teriam mais força e autonomia para estimular a formação e conscientização sobre o tema, fortalecendo as organizações internas de mulheres. Apesar da importância da criação do Setor de Gênero para a organização das mulheres no MST, o Jornal Sem Terra parece não atentar para isso, e a primeira publicação sobre mulheres, a partir de 2003, é só na edição de Março de 2004.

O que as publicações analisadas nesse período nos mostram é que a organização de mulheres no MST passa a estabelecer uma relação mais estreita com os movimentos feministas, que incluem movimentos urbanos, como por exemplo, a Marcha Mundial de Mulheres ${ }^{12}$. Esse diálogo com movimentos feministas faz com que, comece a aparecer nas publicações sobre as mulheres sem terra, a palavra "feminismo" e adoção da identidade coletiva "camponesa", influenciada, por sua vez, pelo ingresso do MST na Via Campesina e adoção dessa linguagem política pelo Movimento. Nesse sentido, percebe-se que no percurso da organização política das mulheres do MST as identidades coletivas se alteraram. Inicialmente estas mulheres se reivindicavam enquanto "mulheres trabalhadoras rurais" ou "mulheres sem terra". Entretanto, a partir da entrada do Movimento na Via Campesina passou a ser construída a identidade de "mulheres camponesas". Este é um trabalho de construção política interna, mas se relaciona diretamente com o novo posicionamento do MST, de certo distanciamento da CUT (onde a identidade de trabalhadora rural era usada de forma mais ampla), para ter maior relação com movimentos sociais de outros países. A afirmação da identidade camponesa demarca essa diferença. A observação de como se

\footnotetext{
12 A Marcha Mundial de Mulheres (MMM) surge em 2000 e é uma organização de mulheres urbanas e rurais articuladas com os movimentos sociais, que visa construir uma perspectiva feminista no enfrentamento à pobreza e exploração e na construção de um novo projeto de sociedade.
} 
As mulheres do MST na luta pela terra e por fazer-se em sujeitos políticos | lolanda Araujo F. dos Santos \& Everton L. Picolotto

constrói a identidade coletiva assumida nesses diferentes movimentos - e em diferentes momentos - nos remete à Melucci (2001, p. 23) que aponta que a identidade coletiva é "produto de trocas, negociações, decisões, conflitos entre atores", não só internamente, mas também pelas relações com concorrentes e aliados é que o ator coletivo se forma e se modifica ao longo do tempo.

Muitas notícias dessa fase organizativa retratam a mobilização e importância das mulheres do MST na luta pela transformação social, por um novo projeto de sociedade, temas como Agroecologia e biodiversidade ganham força nos debates e ações das mulheres camponesas (destaca-se aí a ação na empresa Aracruz ${ }^{13}$, como símbolo da luta contra as transacionais do campo). Nesse contexto, reforça-se em notícias que incluem a Marcha Mundial de Mulheres, a necessidade de diálogo entre mulheres do campo e da cidade para que unidas possam ter mais força na luta de classes, isso demonstra também a busca de outras referências para pensar a questão da mulher rural, para além das orientações da Igreja.

As pautas em torno das quais as mulheres do MST se mobilizam com mais força nessa fase organizativa ficam claras em uma notícia publicada na edição março de 2004 do JST, que relata que no dia internacional da mulher as mulheres rurais foram às ruas para reivindicar um projeto popular para o Brasil, a proibição dos alimentos transgênicos, a geração de empregos, implantação da reforma agrária, saúde, moradia e educação e por uma sociedade que seja justa e igualitária para mulheres e homens. Nesta reportagem, após uma exposição sobre como se dá a dominação masculina e como a desvalorização da mulher se faz presente, inclusive nos movimentos de esquerda, aparece, pela primeira vez nas publicações do JST, a palavra "feminismo", mencionada na fala de uma militante da Marcha Mundial de Mulheres: "Queremos desmistificar a palavra feminismo, que não é brigar com os homens e não gostar deles. Feminismo é lutar pela igualdade entre todas as pessoas. Essa igualdade é o elemento estruturados da sociedade que lutamos para construir". Inferimos que é, a partir dessa articulação com mulheres urbanas que o debate direto sobre feminismo vai sendo inserido no

\footnotetext{
13 Em uma ação mobilizada pelas mulheres camponesas no dia 8 de março de 2006, 1.800 mulheres da Via Campesina, organizadas, ocuparam o viveiro hortoflorestal da Aracruz Celulose, no municipio de Barra do Ribeiro, que fica a cerca de duas horas de Porto Alegre-RS. Na ação, as mulheres destruíram estufas e bandejas de mudas de eucalipto como protesto contra a monocultura, denunciando seus maleficios sociais e ambientais.
} 
As mulheres do MST na luta pela terra e por fazer-se em sujeitos políticos | lolanda Araujo F. dos Santos \& Everton L. Picolotto

MST. A edição de fevereiro de 2005 apresenta um cartaz da Marcha Mundial de Mulheres (MMM) com a frase "Mulheres em movimento mudam o mundo!". A apresentação desse cartaz no Jornal Sem Terra demonstra que está de fato havendo certo diálogo e articulação das mulheres do MST com a MMM.

$\mathrm{O}$ ato mobilizado pelas mulheres camponesas que mais repercutiu nacionalmente foi noticiado pelo Jornal Sem Terra em março de 2006. Nesse mês, duas mil mulheres da Via Campesina ocuparam o horto florestal da empresa Aracruz Celulose, no Rio Grande do Sul e causaram uma repercussão nacional e internacional com esse ato contra os desertos verdes e as transnacionais da agricultura, tendo em vista que neste mesmo período ocorria em Porto Alegre, a "Conferência Internacional sobre Reforma Agrária e Desenvolvimento Rural" (promovida pela Food and Agriculture Organization of the United Nations - FAO e o Governo Brasileiro). Esses fatos mostram uma vez mais que com a vinculação do MST à Via Campesina as mulheres passam a assumir mais a identidade de "mulheres camponesas", concomitante a isso começam a aparecer nas notícias como maior força temas como agroecologia, biodiversidade, luta contra desertos verdes, que são temas articuladores do projeto de agricultura camponesa.

A edição de junho de 2004, por exemplo, divulga que "mulheres discutem conjuntura politica e social". Conforme publicado, mulheres rurais da América, África, Europa, Ásia, Caribe e Oriente Médio que participaram, no Brasil, da IV Conferência Internacional da Via Campesina, realizaram a II Assembleia Mundial de Mulheres do Campo. No evento foi possivel discutir e trocar experiências. Apesar dessa ser uma notícia sem destaque e sem maiores informações no JST, identifica-se nesse acontecimento um relevante salto organizativo para as mulheres do MST, discutindo, trocando experiências e se articulando a nivel internacional em torno de pautas politicas.

Em fevereiro de 2006 o Jornal Sem Terra publica um texto intitulado "A participação da mulher na transformação social”. O texto atenta para o fato de que as mulheres precisam ser sujeitas da construção de um projeto popular, não só no futuro. Nessa publicação as mulheres destacam que é preciso garantir a participação feminina no presente e que as organizações da classe trabalhadora precisam aprender um novo jeito de fazer a luta de classes, respeitando as diferenças e desigualdades, e assim criando condições 
As mulheres do MST na luta pela terra e por fazer-se em sujeitos políticos | lolanda Araujo F. dos Santos \& Everton L. Picolotto

para a efetiva participação das mulheres. É preciso ampliar a participação das mulheres nos espaços de decisão politica e econômica, bem como promover formação de lideranças femininas e combater internamente as desigualdades, como pontua o texto: "A luta pelo socialismo precisa incorporar o feminismo e nesse campo muitas cercas ainda precisam ser rompidas. A maioria dos homens e mulheres que dizem não gostar do feminismo nem sabem o que ele significa".

Em março/2007 o Jornal Sem Terra publica um texto intitulado "Mulheres do campo e da cidade unidas na construção do projeto popular". Esse texto fala sobre a necessidade de construir bandeiras em comum entre as mulheres rurais e urbanas e sobre a importância da participação das mulheres na luta de classes. O texto chama atenção para o fato de que as mulheres pobres, sejam elas do campo ou a cidade, precisam lutar contra os mesmos inimigos: o machismo e o neoliberalismo, por isso é importante que as mulheres se unam como pertencentes de uma mesma classe social. A reportagem também fala sobre como as mulheres foram despertando para lutas que não são tratadas como "coisa de mulher", como por exemplo a luta contra os transgênicos e as transnacionais. A entrevistada, militante da Marcha Mundial de Mulheres, afirma que essas lutas precisam ter um olhar feminista, pois a vida das mulheres também sofre influência disso:

Nós temos que construir um feminismo de classe. Não dá pra acreditar
que a submissão e a exploração sofrida por uma mulher pobre, seja a
mesma de uma mulher rica. Nós só vamos acabar com a desigualdade
de gênero, se acabarmos com a de classe. Temos total clareza disso.
Ter um feminismo classista é fundamental para acabar com a
desigualdade entre homens e mulheres.

Percebe-se nesse discurso uma mudança na forma de enxergar a relação entre classe e gênero, visto que no início do MST e da mobilização das mulheres no Movimento nos anos de 1980, a problematização era de que a luta de classes poderia invisibilizar as questões de gênero (a luta feminista), enquanto a partir dos anos 2000 o discurso é de que a luta feminista precisa assumir o viés classista.

As edições do Jornal Sem Terra de abril de 2007, março de 2008, março de 2010 e abril de 2010 tem foco nas atividades das mulheres em alusão ao dia Internacional da Mulher, o 8 de março. As notícias falam sobre a instituição da data e sobre a luta das mulheres Sem Terra. De acordo com 
As mulheres do MST na luta pela terra e por fazer-se em sujeitos políticos | lolanda Araujo F. dos Santos \& Everton L. Picolotto

a notícia, as mulheres demonstram sua força nas lutas da classe trabalhadora, por Reforma Agrária e pelo fim da discriminação, e o 8 de março é o dia em que as mulheres "assumem o comando". A data é uma motivação para as mulheres colocarem em pauta temas politicos e participarem como protagonistas das lutas sociais. O MST adotou essa data como um marco que inicia as lutas de cada ano, e também como um dia de debate do modelo agrícola. "As mulheres sofrem o impacto de um modelo de agricultura perverso e tomam consciência que precisam ir para o enfrentamento e mostra para a sociedade que há um projeto alternativo de agricultura camponesa." As lutas que marcam essa data seguem a perspectiva de combate ao latifúndio e à hegemonia das transnacionais no campo.

A edição de agosto de 2009 traz um texto da coordenadora da Sempreviva Organização Feminista (SOF) ${ }^{14}$ sobre o livro "O segundo sexo", de Simone de Beauvoir, com apontamentos sobre as ondas do feminismo e atualidade desse debate em comemoração aos 80 anos da obra. Apesar do texto ser primordialmente teórico, é importante assinalar que ele representa uma entrada significativa do debate do feminismo no MST.

Na edição de abril 2010 o JST traz uma entrevista com a assentada Irene Manfio que produz de forma cooperativada e fala sobre a importância da participação das mulheres no setor de produção e nas cooperativas. A entrevistada destaca que as mulheres se identificam com o debate da agroecologia e que esse debate só vai avançar de fato quando as mulheres participarem e "tomarem para si" essa tarefa. Ainda, segundo Irene, com a produção em cooperação as mulheres tem mais chances de participar. Carneiro (1994) chama atenção para o fato de que décadas atrás a mulher só podia se associar nas cooperativas se fosse viúva ou solteira. Essa proibição impedia a mulher casada de receber remuneração de seu próprio trabalho, sendo o direito de cooperativar-se uma reivindicação estritamente relacionada à mudança da posição da mulher na hierarquia familiar, onde finalmente ela poderia ter autonomia para gerir seus próprios recursos. A problemática da participação da mulher na produção nos assentamentos é tratada por Ferrante et al., (2013), onde os autores discutem que nos assentamentos as

${ }^{14}$ A SOF é uma organização não governamental, que assessora organizações de mulheres e movimentos mistos a partir do feminismo. 
As mulheres do MST na luta pela terra e por fazer-se em sujeitos políticos | lolanda Araujo F. dos Santos \& Everton L. Picolotto

decisões sobre produção não passam pelas mulheres, mesmo no caso de mulheres titulares, são poucas que comandam o trabalho no lote. Ferrante et al., (2013) argumentam que a inserção das mulheres como protagonistas de práticas diferenciadas da agricultura convencional podem ser positivas para a construção de uma outra relação das mulheres com a política de assentamentos rurais e com o próprio movimento. De acordo com esses autores, a inserção das mulheres em atividades de diversificação de renda é uma opção necessária para se discutir o futuro dos assentamentos em modelos alternativos ao agronegócio.

"Compromisso de luta das mulheres sem terra" é um texto publicado na edição de fevereiro/2012 que fala sobre a luta das mulheres no 8 de março ao longo dos anos, e como as mulheres têm se construído politicamente em torno dessa data. "A luta das mulheres produziu um novo sujeito político no interior do MST: a militância feminista." Nota-se nessa notícia que, além do reconhecimento do feminismo, existe o reconhecimento da mulher enquanto sujeito político: a "militante feminista". A notícia também fala que é importante construir lutas que dialoguem com a sociedade, não apenas as mulheres, e o que mais tem conseguido apoio popular é a luta contra o agronegócio, transgênicos, e violência.

Em agosto de 2012 o Jornal Sem Terra divulga edição onde consta o relato das mobilizações das mulheres na Cúpula dos Povos. Essa mobilização foi organizada pela Marcha Mundial de Mulheres, e não especificamente pelas mulheres da Via Campesina. As mulheres exigiram o fim da violência contra as mulheres, a legalização do aborto, condições justas de trabalho e salário, e o fim do modelo capitalista. A pauta da legalização do aborto é uma novidade entre as pautas das mulheres do MST e indica ainda certo distanciamento da influência da Igreja. Percebe-se que há uma mudança nas referências que influenciavam as mulheres do MST. Se nos primórdios do Movimento os setores progressistas da Igreja Católica eram uma das principais referências e influências para a mobilização feminina, a partir da aproximação do MST com demais movimentos sociais (especialmente após compor a Via Campesina) e do diálogo das mulheres Sem Terra com movimentos autônomos de mulheres rurais e movimentos feministas em geral, além do acesso a universidades e outros espaços de formação, acabou abrindo o leque de 
As mulheres do MST na luta pela terra e por fazer-se em sujeitos políticos | lolanda Araujo F. dos Santos \& Everton L. Picolotto

referências e influências o que reflete na diversidade de pautas encampadas pelas mulheres do MST nesse período até os dias atuais.

Conforme observado no relato das edições do Jornal Sem Terra, as mobilizações das mulheres camponesas se dão primordialmente contra o agronegócio, o modelo de desenvolvimento imposto, e a favor de alternativas sustentáveis de desenvolvimento da agricultura e da sociedade. Esse fato é também constatado por Aguiar (2016) sobre a ação das mulheres rurais na Marcha das Margaridas ${ }^{15}$. Ao estudar a Marcha das Margaridas, Aguiar (2016) observa que para construir a marcha os movimentos e organizações de mulheres tem se articulado em redes onde interagem diversos atores, grupos e discursos. A finalidade dessa articulação que acaba gerando um movimento heterogêneo e múltiplo cuja finalidade é produzir visibilidade e impacto na esfera pública. Em rede, as mulheres do campo, da floresta e das águas que constroem a Marcha das Margaridas extrapolam as demandas locais e as especificidades de "mulher trabalhadora rural", conectando suas especificidades à questões mais gerais. Sobre isso, Aguiar (2016) aponta que os diversos movimentos de mulheres que se integram à Marcha das Margaridas ampliam suas bandeiras de lutas específicas traduzindo-as em significados maiores com foco em um novo modelo de desenvolvimento:

Ao afirmar sua fundamental importância para a construção de um projeto que se opõe ao modelo de desenvolvimento capitalista e patriarcal, acaba por expressar uma luta que é anticapitalista e antipatriarcal como transversal na luta por mudanças sociais, recebendo, nesse sentido, a adesão de mulheres urbanas, que, por fim, se reconhecem, também, em torno das questões trazidas pelas mulheres do campo e da floresta, o que faz com que a Marcha, a cada ano, venha tendo uma participação mais significativa das "mulheres urbanas" (AGUIAR, 2016, p. 286).

A Marcha das Margaridas é um exemplo de que as reinvindicações relacionadas a temas produtivos e vinculados a um projeto estratégico de desenvolvimento rural se somou às reivindicações históricas das mulheres rurais, como as questões previdenciárias e de direitos sociais. Essas "novas" lutas questionam a ação do agronegócio e reafirma a importância da

\footnotetext{
15 A Marcha das Margaridas aconteceu pela primeira vez em agosto do ano 2000, é um movimento de mulheres do campo e da floresta que se manifesta em forma de uma "marcha" na capital do país, buscando dar visibilidade às demandas dessas mulheres. O nome desse movimento é em alusão à trabalhadora rural e lider sindical Margarida Alves. A Marcha das Margaridas ocorre a cada 4 anos, mobilizando milhares de mulheres rurais.
} 
As mulheres do MST na luta pela terra e por fazer-se em sujeitos políticos | lolanda Araujo F. dos Santos \& Everton L. Picolotto

agricultura familiar, além de questionar o papel da mulher na sociedade (AGUIAR, 2016).

Fraser (2007) após criticar o fato de o feminismo ter se afastado das questões de classe e das lutas por redistribuição de renda sinaliza que algumas correntes feministas estão se esforçando em construir uma nova sintese entre redistribuição e reconhecimento, mudando a escala política feminista. Conscientes da vulnerabilidade das mulheres às forças transnacionais e diante da produção transnacionalizada, muitas feministas vão além das economias nacionais, rompendo as barreiras territoriais para enfrentar a injustiça de gênero nas relações sociais transnacionais (FRASER, 2007), talvez seja esse o caminho que está sendo trilhado pelas mulheres camponesas ao empenhar esforços na luta contra o capital globalizado.

\section{Considerações Finais}

A análise das notícias publicadas no Jornal Sem Terra, especialmente àquelas que relatam as ações e mobilizações públicas das mulheres do MST, nos leva a inferir, concordando com Carneiro (1994), que a participação das mulheres no Movimento de Trabalhadores Sem Terra não era motivada por sua condição de mulher, mas sim contra a exploração ou expropriação de sua categoria social, ou seja, o que mobilizava as mulheres para a luta era o pertencimento em uma categoria social e política, uma identidade coletiva que incluía homens e mulheres. Nesse sentido, Carneiro (1994) reforça que, anterior à construção das distinções sociais entre gêneros, formou-se a noção de igualdade entre homens e mulheres na luta contra a desigualdade social.

Ao realizar também um trabalho de análise de documentos do MST, Furlin (2013) considera que no MST, a luta pela reforma agrária tem evoluído e ultrapassado cada vez mais a conquista da terra, acrescentando à essa luta questões mais amplas como o compromisso com uma educação de qualidade, a preservação do meio ambiente e conquista da cidadania plena para homens e mulheres. De acordo com a autora, a incorporação dessas lutas implica para o movimento a busca por transformações societárias mais amplas. É importante destacar que o processo de incorporação das questões de gênero pelo MST é uma conquista da organização de mulheres, e não uma iniciativa espontânea do Movimento. Furlin (2013) também coloca a influência de 
As mulheres do MST na luta pela terra e por fazer-se em sujeitos políticos | lolanda Araujo F. dos Santos \& Everton L. Picolotto

fatores externos que pressionaram o MST para que este abrisse espações de participação para mulheres, esses fatores externos incluem desde os convites para a representação da organização de mulheres assentadas eventos internacionais, até a exigência das agências financiadoras pela transversalidade de gênero nas ações. O debate acadêmico e a organização e pressão interna das mulheres são também fatores significativos para a incorporação da perspectiva de gênero pelo MST.

O esforço empreendido nas análises das publicações do JST nos permite fazer algumas considerações sobre o desenvolvimento e evolução das questões de gênero no interior do MST. As mulheres que iniciaram o processo de organização dentro do MST já eram militantes das CEBs, CPT e Centrais Sindicais, ou seja, existia certa experiência e vivência militante dessas mulheres que é anterior ao MST e que contribui para a inserção politica dessas mulheres. De acordo com Thompson (1981) a experiência é gerada na "vida social" e estruturada em termos de "classe" onde consequentemente o ser social determina a "consciência social". Assim podemos inferir que é a experiência, ou a experimentação de situações e relações que produzem a consciência de classe, ou no caso das mulheres rurais, que produzem a consciência de classe e gênero.

Os eventos, encontros e congressos se constituíam como espaços de formação e também de estímulo para a participação das mulheres, além de serem importantes fontes de diversificação de referências e influências para as militantes que por um tempo tinham como principal influência as orientações dos setores mais progressistas da Igreja Católica. É importante mencionar ainda que a própria pedagogia do Movimento foi fundamental para a construção subjetiva das mulheres como ator coletivo. Nesse sentido, destaca-se a ciranda infantil, estratégia para que as mães do MST pudessem participar dos espaços políticos do Movimento e também a possibilidade de formação acadêmica das mulheres Sem Terra, através dos cursos superiores ofertados pelo Programa Nacional de Educação Para a Reforma Agrária (PRONERA). A pauta da educação no MST se constitui como importante a partir da luta das mulheres e pelo reconhecimento da importância da participação das mulheres e crianças no Movimento como um todo. 
As mulheres do MST na luta pela terra e por fazer-se em sujeitos políticos | lolanda Araujo F. dos Santos \& Everton L. Picolotto

As mulheres inicialmente se mobilizaram por direitos considerados básicos para a cidadania, como o direito à documentação, ao reconhecimento profissional e a direitos trabalhistas e previdenciários, pautas que pareciam pouco avançadas se comparadas às pautas do movimento feminista urbano, talvez por isso existia dificuldades de identificação das mulheres Sem Terra com o feminismo. A luta das mulheres do MST não se reduzia às chamadas "questões de mulher", mas representavam um enfrentamento e uma resistência das mulheres camponesas ao agronegócio e um compromisso com a luta por reforma agrária, particularidades que não são comumente abordadas pelo movimento feminista em geral, assim, são raras as notícias que relacionam a organização das mulheres do MST com a palavra "feminismo".

Percebe-se que a identidade coletiva, como define Melucci (2001), é interativa e compartilhada, vai sendo alterada e redefinida conforme as articulações internas e externas vão configurando opções: inicialmente elas se identificavam como "trabalhadoras rurais" ou "mulheres sem terra", nos anos 2000 passou a circular a identidade de "mulher camponesa".

Não existe uma identificação direta das militantes do MST com o feminismo, entretanto, embora por muito tempo as mulheres do MST não tenham se mobilizado especificamente em torno da questão de gênero, é essa experiência e trajetória de luta pela terra que as forja enquanto sujeitos políticos que passam a reivindicar também a construção de relações de gênero mais igualitárias e se aproximar do feminismo.

Por fim, destacamos a importância e riqueza do estudo documental e histórico para a análise da trajetória de lutas e para observar as diversas fases da construção das mulheres como sujeitos políticos um movimento social como o MST. Almejamos que os dados documentais apresentados nesse artigo possam instigar mais questionamentos e reflexões acerca do tema.

\section{Referências Bibliográficas}

AGUIAR, V. V. P. Mulheres rurais, movimento social e participação: reflexões a partir da Marcha das Margaridas. Revista Política \& Sociedade, v. 15. 2016

BORDALO, C.A. Os caminhos da política: o sindicalismo rural e os movimentos de mulheres trabalhadoras rurais em Pernambuco. 2011. 158p. 
As mulheres do MST na luta pela terra e por fazer-se em sujeitos políticos | lolanda Araujo F. dos Santos \& Everton L. Picolotto

Dissertação (Mestrado em Ciências Sociais em Desenvolvimento, Agricultura e Sociedade) - Universidade Federal do Rio de Janeiro, RJ, 2011.

CARNEIRO, M. J. Mulheres no campo: notas sobre sua participação política e a condição social do gênero. Revista Estudos Sociedade e Agricultura. Rio de Janeiro. p.11-22. 1994.

CORADINI, Odacir. Ambivalência na representação de classe e a noção de "trabalhador rural". In: NAVARRO, Z. (org.). Política, protesto e cidadania no campo. Porto Alegre: Ed. UFRGS, 1996.

DEERE, C.D. Direitos da mulher à terra e os movimentos sociais rurais na reforma agrária brasileira. R. Estudos Feministas, Florianópolis, v.12, n.1, p. 175- 204, jan.-abr./2004.

ESMERALDO, G. G. O protagonismo politico de mulheres rurais por seu reconhecimento econômico e social. In: NEVES, Delma P.; MEDEIROS, Leonilde S.de (Orgs.). Mulheres camponesas: trabalho produtivo e engajamentos políticos. Niterói: Alternativa, 2013. p. 237-256.

FERRANTE, V.L.S.B; DUVAL, H.C; BERGAMASCO, S.M.P.P; BOLFE, A.P.F; $\mathrm{Na}$ trajetória dos assentamentos rurais: mulheres, organização e diversificação. In: NEVES, Delma P.; MEDEIROS, Leonilde S.de (Orgs.). Mulheres camponesas: trabalho produtivo e engajamentos políticos. Niterói: Alternativa, 2013. p. 195-216.

FRASER, N. "Mapeando a imaginação feminista": da redistribuição ao reconhecimento e à representação. Revista Estudos Feministas, 15(2), 291308. 2007

FURLIN, N. A perspectiva de gênero no MST: um estudo sobre o discurso e as práticas de participação das mulheres. In: NEVES, Delma P.; MEDEIROS, Leonilde S.de (Orgs.). Mulheres camponesas: trabalho produtivo e engajamentos políticos. Niterói: Alternativa, 2013. p. 257-284.

GONÇALVES, R. (Re)politizando o conceito de gênero: a participação política das mulheres no MST. Dossiê: contribuições do pensamento feminista para as Ciências Sociais, Mediações, Londrina, v. 14, n. 2, p. 198-216, jul./dez. 2009.

MELUCCI, A. A invenção do presente. Rio de Janeiro: Vozes, 2001.

MOVIMENTO DOS TRABALHADORES RURAIS SEM TERRA. A questão da mulher no MST. MST. São Paulo: MST, 1996.

MOVIMENTO DOS TRABALHADORES RURAIS SEM TERRA. Caderno de Formação n 02: mulher sem terra. São Paulo: MST [19--].

MOVIMENTO DOS TRABALHADORES RURAIS SEM TERRA. Caderno de Formação $n^{\circ}$ 15: a mulher nas diferentes sociedades. São Paulo: MST, 1988.

PAULILO, M. I. S. Trabalho familiar: uma categoria esquecida de análise. R. Estudos Feministas, v.12, n.1, p. 229-252, jan.-abr./2004. 
As mulheres do MST na luta pela terra e por fazer-se em sujeitos políticos | lolanda Araujo F. dos Santos \& Everton L. Picolotto

PICOLOTTO, E. L. As Mãos que Alimentam a Nação: agricultura familiar, sindicalismo e politica. 2011. 289p. Tese (Doutorado em Ciências Sociais em Desenvolvimento Agricultura e Sociedade) - Universidade Federal Rural do Rio de Janeiro, Rio de Janeiro, RJ, 2011.

THOMPSON, E. P. A miséria da teoria ou um planetário de erros uma crítica ao pensamento de Althusser. Rio de Janeiro: ZAHAR, 1981.

THOMPSON, E. P. Costumes em comum: estudos sobre a cultura popular tradicional. São Paulo: Companhia das Letras, 1998. 